This is the accepted version of an article published by Wiley in The British Journal of Sociology. Published version available from: https://doi.org/10.1111/1468-4446.12338

Accepted version downloaded from SOAS Research Online: http://eprints.soas.ac.uk/25219/

\title{
Conjugal intimacy, gender and modernity in contemporary China
}

Jieyu Liu, Eona Bell and Jiayu Zhang

SOAS China Institute, SOAS University of London

\begin{abstract}
The new generation of modernity theorists have forecast the democratization of gender relations within intimate relationships in late-modern times. Chinese society has undergone rapid and dramatic changes in its unique trajectory of political, social and economic reform. Using China as an example of a region which has been largely ignored in contemporary social theory, this article enters the debate to contest the extent to which conjugal relationships are democratized in line with modernity. We further test the assertion that modern marriages are characterized by increased selfdisclosure and communication between partners.
\end{abstract}

Data from a national survey on Chinese families is analysed in relation to the level of self-disclosure between husbands and wives; gender division of housework; household decision-making; and home ownership. We highlight the impact of gender, cohort and location (urban, rural or migrant) on experiences of modernity and draw attention to the material, social and cultural factors which continue to shape conjugal relations in contemporary Chinese society. Based on our findings, we contest the argument that disclosing intimacy between intimate partners is a defining characteristic of modern relationships, and suggest that other social factors may 
This is the accepted version of an article published by Wiley in The British Journal of Sociology. Published version available from: https://doi.org/10.1111/1468-4446.12338

Accepted version downloaded from SOAS Research Online: http://eprints.soas.ac.uk/25219/

condition degrees of self-disclosure in marriage. Similarly, we question the extent to which heterosexual conjugal equality is attained: the cultural practices and values of patrilineal family organization, together with material circumstances, continue to influence marital relations in China.

\section{Keywords}

Conjugal intimacy, self-disclosure, gender, cohort, urban-rural divide, China 
This is the accepted version of an article published by Wiley in The British Journal of Sociology.

Published version available from: https://doi.org/10.1111/1468-4446.12338

Accepted version downloaded from SOAS Research Online: http://eprints.soas.ac.uk/25219/

\section{Introduction}

Intimate relationships have featured prominently in the work of new modernity theorists. It is argued that negotiation and contingency have become more prominent in intimate relationships within modern societies (Beck and Beck-Gernsheim 1995). Giddens (1992) describes a shift in the late twentieth century from romantic love to the 'pure relationship', characterized by 'confluent love' where individuals stay together only insofar as their self-development and erotic needs are being met. In this new type of intimacy, the key emphasis is on 'opening oneself to the other' (Giddens 1992: 61) in 'a process of mutual disclosure' (Giddens 1991: 6). This transformation of intimacy entails 'democratising of the interpersonal domain, in a manner fully compatible with democracy in the public sphere' (Giddens 1992: 3).

While feminist scholars accept that intimate relationships have diversified (Stacey 1996), many dispute the extent to which democratization is taking place in the democratic societies which Giddens describes (Jamieson 1998). Discussing the literature on Euro-American family relationships, Jamieson argues that while disclosing intimacy may be more evident in modern relationships, it is not the key organizing principle of personal lives. Finally, scholars have questioned the ethnocentrism underlying such claims concerning modernity and intimacy (Jackson 2015). Others have shown that traditional gender norms persist despite economic development in some regions, such as East Asia (Chang and Song 2010).

This article joins the debate on intimacy in modern relationships. We explore this in the context of China's developmental trajectory of political engineering and 
This is the accepted version of an article published by Wiley in The British Journal of Sociology. Published version available from: https://doi.org/10.1111/1468-4446.12338

Accepted version downloaded from SOAS Research Online: http://eprints.soas.ac.uk/25219/

economic reform over the past half-century. By analysing national survey data on marital relations, we highlight the impact of gender, cohort and location (urban, rural or migrant) on experiences of modernity and disclosing intimacy, drawing attention to the material, social and cultural factors which continue to shape conjugal relations in contemporary Chinese society. We question the democratization of intimate relationships in the context of gendered difference in access to the labour market, and enduring gender norms in Chinese culture.

\section{Changing Marital Relations in China}

In Chinese history, conjugal relationships were not always valued, since Confucian tradition dictated that inter-generational relations and duty to continue the male descent line took precedence over marital quality, individual needs or desires (Wolf 1972). Furthermore, male polygamy has been a deeply entrenched social norm at almost all levels of Chinese society, giving little room for ideals of the exclusive relationship between two intimates. The twentieth century saw enormous changes to marriage and family practices in China. Social movements from the early 1900s demanded greater freedom from family control for both women and young people (Baker 1979) and in 1930, the Republican government introduced new family law enhancing the rights of wives (Kuo 2012). In urban elite culture of the Republican period, adherents to the new ideology of love-based marriage adopted the term lian'ai to refer to relationships liberated from filial duty (Pan 2015: 279). Lian'ai came close to the European understanding of romantic love, elevating spiritual love over bodily desire. Nonetheless, its cultural roots in China were shallow, and Pan (2015) argues that the political and social drive towards revolution overwhelmed any early twentieth-century developments to the Chinese cultural model of marriage. 
This is the accepted version of an article published by Wiley in The British Journal of Sociology. Published version available from: https://doi.org/10.1111/1468-4446.12338

Accepted version downloaded from SOAS Research Online: http://eprints.soas.ac.uk/25219/

More change followed the foundation in 1949 of the People's Republic of China (PRC), as women increasingly entered the paid workforce, and the 1950 Marriage Law established a socialist model of marriage, eliminating arranged marriages. However, communist ideology left little room for romance, and young people were encouraged to marry for the sake of mutual encouragement in work and study (Croll 1979). In the post-Mao era, decentralization and other neoliberal economic doctrines have introduced a 'socialist market economy' (Dirlik and Zhang 1997). Dating and premarital sex have become more widely accepted, particularly in urban areas, and the divorce rate has increased (Wang 2001); however, marriage remains a nearuniversal experience for Chinese men and women (Liu 2004). Concerning marital relations, there has been the gradual convergence of expectations and practices towards Euro-American norms, in which the emotional quality of marriage is prioritized (Xu 1999; Pimentel 2000; Farrer 2002). Public discourse has promoted an ideal of marriage as a relationship of love and mutual companionship, while the trend towards free-choice marriages has intensified (Yan 2003). However, there is contrary evidence that material concerns have increased in relation to marriage (Zhang 2000). A new marriage law was passed in 1980, liberalizing divorce and advancing women's property rights, although recent changes to family law have disadvantaged married women in relation to home ownership: a woman has no automatic rights in the marital home unless her name is on the property deeds. In brief, this is a complex time when paradoxes and conflicts at both individual and social levels abound, making contemporary China an ideal empirical case study for theoretically assessing modernity and intimate relationships. Existing scholarship on marital relationships in China have not engaged with the wider sociological debate on intimacy and 
This is the accepted version of an article published by Wiley in The British Journal of Sociology. Published version available from: https://doi.org/10.1111/1468-4446.12338

Accepted version downloaded from SOAS Research Online: http://eprints.soas.ac.uk/25219/

modernity; therefore, our work brings the Chinese case into the consideration of current discussions.

\section{Modernity, disclosing intimacy and democratization of intimate relations}

In his landmark works on self, intimacy and modernity, Giddens $(1991,1992)$ talks about the ascendancy of the 'pure relationship', that is 'one in which external criteria have become dissolved: the relationship exists solely for whatever rewards that relationship can deliver' (Giddens 1991: 6). The first feature of this pure relationship is that it is mainly sustained through mutual self-disclosure: constantly revealing one's inner feelings to the other (Giddens 1991). Jamieson (1998: 158) calls this 'disclosing intimacy' - 'a process of two people mutually sustaining deep knowing and understanding, through talking and listening, sharing thoughts, showing feelings'. The second feature of the pure relationship is that it is 'a relationship of sexual and emotional equality, which is explosive in its connotations for pre-existing forms of gender power' (Giddens 1992: 2). As Giddens writes, 'a democratisation of the private sphere is today not only on the agenda, but is an implicit quality of all personal life which comes under the aegis of the pure relationship' (Giddens 1992: 184).

Jamieson (1999) has challenged Giddens' optimistic view of the transformative effects of the pure relationship on gender equality in modern societies. Firstly, she points out that Giddens fails to acknowledge feminist scholarship which has concluded that women's greater power within marriage does not necessarily lead to gender equality in public life and institutions. Pre-existing social structures have not 
This is the accepted version of an article published by Wiley in The British Journal of Sociology. Published version available from: https://doi.org/10.1111/1468-4446.12338

Accepted version downloaded from SOAS Research Online: http://eprints.soas.ac.uk/25219/

declined since class and gender, for example, remain important (Jamieson 1998;

Duncan and Irwin 2004). Furthermore, in practice, every domestic partnership must deal with practical, material and financial matters which seem to negate the possibility of a 'pure relationship' disengaged from such concerns. Jamieson (1998) also questions the emphasis on self-disclosure, arguing that disclosing intimacy is not necessarily becoming the key or central focus of personal life: instead, Jamieson suggests, intimacy may be evident in acts of practical care.

Jackson (2015) further points out the ethnocentrism which underlies the assertions of new modernity theorists. Her argument draws our attention to how local social, economic, political and cultural configurations shape the contours of intimate relationships. For example, in Japan, ideologies of equality co-exist with patriarchy, allowing women to take paid work yet preserve their domestic roles at home (Hashimoto and Traphagan 2008). Middle-class Gujarati women in India seek loving, companionate marriages but also husbands who are educationally and professionally superior to them, and thus able to support a stay-at-home wife; considerations of caste status remain important for these 'traditional-modern' women (Twamley 2014). In a study which may have resonance for post-Mao China, Lišková (2016) argues that sexual discourses in communist Czechoslovakia were formed in a reversed order, with liberalization preceding conservatism; this was because of the changing character of the regime which accentuated public life, work and equality in the 1950s, but then privacy, family and authority in the 1970 s. 
This is the accepted version of an article published by Wiley in The British Journal of Sociology. Published version available from: https://doi.org/10.1111/1468-4446.12338

Accepted version downloaded from SOAS Research Online: http://eprints.soas.ac.uk/25219/

This article joins other responses to the Eurocentrism of much contemporary theorizing on intimacy and modernity by testing Giddens' two key arguments disclosing intimacy and the democratization thesis - using national survey data from the Chinese General Social Survey (CGSS) on marital relations in China. We choose to focus on conjugal intimacy for two reasons: first, the term 'intimacy' was initially used in academic studies in the context of couple intimacy and this remains core to much research in this area (see Jamieson 1998; Jackson 2015). Second, despite the many social changes, marriage remains the dominant form of intimate relationship for Chinese adults, with the 2010 census showing that only 2.47 per cent of women over thirty had never been married (China News Weekly 2015).

\section{Measurement and hypotheses}

\section{Disclosing intimacy and modernity}

Our first task is to measure 'disclosing intimacy' ${ }^{1}$. In this particular type of intimacy, the emphasis is on mutual disclosure; more specifically, it is 'opening oneself out to the other' (Giddens 1992: 61). This emphasis on emotional expressiveness in relationships has been found in recent studies of Chinese couples. Jankowiak and Li (2017: 65) found among their studies of urban couples in various Chinese cities that 'the new importance placed on creating conjugal love has also altered the ways ordinary men and women think about intimacy and romance... The desire to create and sustain a love union modifies men's and women's behavior away from detached performance of roles, toward a willingness to create bonds of emotional

\footnotetext{
${ }^{1}$ Studies of conjugal intimacy also measure sexual intimacy, but CGSS did not include questions on this topic; further, in order to test Giddens' thesis on modernity and intimacy centred on mutual disclosure, we confine our investigation to disclosing intimacy.
} 
This is the accepted version of an article published by Wiley in The British Journal of Sociology.

Published version available from: https://doi.org/10.1111/1468-4446.12338

Accepted version downloaded from SOAS Research Online: http://eprints.soas.ac.uk/25219/

interdependence and empathic mutuality'. Chen and Lim (2012) also suggest that contemporary Chinese women's marital dissatisfaction is related to frustrations in communication and lack of spousal understanding. Therefore, we use survey questions on self-disclosure to evaluate disclosing intimacy, a particular type of intimacy Giddens emphasized in his modernity thesis.

Notions of modernity have been debated in China as early as the first half of the twentieth century (Pan 2015). Rather than measure what modernity is, here we respond to Jackson's (2015: 1) call to explore 'how we imagine and theorize modernity, gender and intimacy from our differing locations [our emphasis]'. Jackson's plea is framed in the contrast between European and Asian countries; our article goes further by calling for the differentiation of experiences within a country on the path to modernity. We do this by highlighting some of the mediating factors including gender, cohort and location, which we expect to correlate with different experiences of disclosing intimacy.

\section{$\underline{\text { Gender }}$}

Classical modernization theory has rather little to say about gender differences, although women were sometimes portrayed as an anomalous group, less easily made into modern economic or political participants than men (Parsons et al. 1956). New modernity theorists (Bauman 2003; Beck and Beck-Gernsheim 1995; Giddens 1992) conversely all address issues of gender and intimate relationships and see changes in gender relations and personal life as central to late modern social change. However, feminist scholars have criticized their overly optimistic view of gender relations and reveal that inequalities and asymmetries in parenting, domestic divisions of labour 
This is the accepted version of an article published by Wiley in The British Journal of Sociology. Published version available from: https://doi.org/10.1111/1468-4446.12338

Accepted version downloaded from SOAS Research Online: http://eprints.soas.ac.uk/25219/

and emotional work persist in Euro-American societies (Jamieson 1998). Gender also has particular importance in the Chinese setting as it has been one of the core principles in Confucianism which prescribed a patriarchal, patrilineal and patrilocal family system where men officially dominated women (Mann and Zhang 2001). Contemporary studies also reveal that gender has remained a key mechanism shaping work and family life in Maoist and post-Mao China. Despite social reform, gender equality was never fully achieved in terms of equal pay, benefits and opportunities for promotion in urban areas (Liu 2007, Liu 2017); in the countryside, collectivization increased women's participation in agricultural work, but again without the same rewards (Croll 1983). At home, there was little change to the cultural norm of women providing the majority of care for family members, and doing most of the housework (Hershatter 2000). Cook and Dong (2011) argue that the withdrawal of state welfare support in the reform era led to women's retreat from the labour force, and this effect has been particularly strong for middle-aged women who carry the burden of unpaid domestic work.

\section{$\underline{\text { Cohort }}$}

Cohort membership has been found to be an important social structural variable because it embodies a particular set of formative and socio-historical experiences that define life chances and circumstances, and shape familial relations (Alwin and McCammon 2003). In China, the cohort approach has proved profitable in studies which recognize the external influences on individual and family behaviours at particular historical moments. The cohort born in the 1950s grew up during the Cultural Revolution, when the norms of the traditional Chinese family were challenged by social upheaval. After Mao's death, Deng's new 'open-door' policy 
This is the accepted version of an article published by Wiley in The British Journal of Sociology. Published version available from: https://doi.org/10.1111/1468-4446.12338

Accepted version downloaded from SOAS Research Online: http://eprints.soas.ac.uk/25219/

transformed China from a communist country with industrial aspirations to a mixedmarket economy characterized by 'socialism with Chinese characteristics'. The post1980s cohort has grown up during a period typified by 'materialism and consumption, information and the Internet, urban civilisation and globalisation' (Lian 2014). In Jankowiak and Li's studies of urban families, he identifies the significant difference in family behaviour in two urban cohorts: the 'dutiful spouse' model, characteristic of those born from the 1960 s to 1977 , is 'grounded in the ordinary life of family practicalities and explicit duties, stresses the diligent and responsible fulfillment of family duties by both spouses and, when necessary, an accepted sexual division of labor'. By contrast, the cohort born since 1978 conform to the 'emotionally involved' model, in which 'the husband and wife prefer to define themselves as socially interconnected and, ideally, intensely emotionally intertwined' (Jankowiak and Li 2017: 70-72).

\section{$\underline{\text { Urban-rural divide (class) }}$}

New modernity theories of intimacy have been criticized for ignoring class

differences. Previous research in the United States has shown that self-expression in intimate relationships is powerfully shaped by class. In middle-class couples, for instance, intimacy was obtained through the partners' sharing of work-related experiences and projects, or by the "transferring of their professional ethos into the private sphere' (Illouz 1997: 280). The concept of class, which originated in European societies, may not easily translate to the Chinese socio-cultural context; this discussion is, however, beyond the scope of the present paper. Here we use the urbanrural divide to assess the effect of class in shaping intimate relationships as this has been recognized as one of the most important agents of social stratification in China 
This is the accepted version of an article published by Wiley in The British Journal of Sociology.

Published version available from: https://doi.org/10.1111/1468-4446.12338

Accepted version downloaded from SOAS Research Online: http://eprints.soas.ac.uk/25219/

(Hannum et al 2010; Knight and Song 1999). A household registration (hukou) system was introduced in the PRC in 1958 and categorizes Chinese citizens as either 'rural' or 'urban': its original purpose was to control labour and limit the movement of people. Since the reforms of the 1980s, the hukou system has been less strictly enforced, allowing labour migration from the countryside to the cities. However, access to state welfare and government services is still determined by hukou status: regardless of their actual residence, rural hukou holders do not enjoy the same level of education, health care, pensions or other support available to those with urban hukou. As a result of this institutionalized segregation, significant socio-economic inequalities have emerged between core urban areas and their rural periphery demonstrating uneven paths to modernity (Liao and Wei 2012). One consequence is that the income ratio between rural residents and urban residents has reached around 1:4 since the 1990s (Guo 2013). The gap in educational aspirations between urban and rural residents is also considerable: a recent survey found that while 77.6 per cent of urban children aspired to a college degree, only 58.7 per cent of their rural peers expected to remain in education beyond high school (Chen et al 2015). In between urban and rural residents in present-day China are the new rural-urban economic migrants. They are disadvantaged in terms of access to jobs and welfare entitlements in comparison with urban hukou holders but much better off than rural residents in terms of access to cash income.

We acknowledge that the division of our sample by urban, rural and migrant status is very crude as there will be further diversity within each category; however, the urbanrural divide has been recognized as an important factor in family behaviour in China. For example, regional differences have been found in the power relations of married 
This is the accepted version of an article published by Wiley in The British Journal of Sociology. Published version available from: https://doi.org/10.1111/1468-4446.12338

Accepted version downloaded from SOAS Research Online: http://eprints.soas.ac.uk/25219/

couples in urban and rural China, with city wives dissatisfied with the unequal sharing of domestic work (Zuo and Bian 2005) while rural-urban migrant husbands are taking on greater responsibility for household chores (Choi and Peng 2016).

\section{$\underline{\text { Democratization of intimate relations }}$}

Giddens predicts a democratizing of the gender order in intimate relationships as a result of the ascendency of the pure relationship founded on disclosing intimacy. Logically, it seems that married couples who experience more mutual disclosure may enjoy more equal relationships. To test this thesis, we choose three practices housework, decision-making, and home ownership — to measure democratization in Chinese marriages. Division of housework has long been used as an illustration of gender roles within intimate relationships (Hochschild and Machung 1989). Pimentel (2006) reveals how the gender division of household chores has changed in important ways across contemporary Chinese marriage cohorts. Fewer young urban women are left to shoulder the entire burden of domestic work in addition to their paid work when compared to older women. In rural areas, marriages are said to be less egalitarian with wives more likely to take responsibility for unpaid domestic work (Judd 1994). Rural-urban migrant households seem to be a special case, as migration necessitates the renegotiation of division of household labour. This sometimes, but not always results in men taking on greater responsibility for childcare and housework and even adopting a new concept of Chinese masculinity which 'stresses men's dedication to and care of the family, and their responsibility for maintaining family happiness and marital harmony' (Choi and Peng 2016: 104). 
This is the accepted version of an article published by Wiley in The British Journal of Sociology. Published version available from: https://doi.org/10.1111/1468-4446.12338

Accepted version downloaded from SOAS Research Online: http://eprints.soas.ac.uk/25219/

Marital power relations have also been studied in terms of decision-making patterns, and it is assumed that more democratic marriages have more shared decision-making (Kulik 2011), with evidence from European societies of a lessening of husbands' influence (Pleck 1999). Zuo and Bian (2005) document a fairly equal pattern of power-sharing among post-Mao urban couples. Rural-urban migrant husbands have been found to prefer more joint decision-making with their wives in the interests of marital harmony (Zuo 2008) and Choi (2016: 81) finds that Chinese migrant men who communicate more with their wives before taking a decision report holding equal power with their spouses.

Finally, we analyse levels of home ownership by gender, on the assumption that in couples where the wife owns the house herself, or jointly with her husband, the marital relationship overall will be more egalitarian. Compared with other societies where rented housing is the norm, home ownership is a long-established tradition in China. Owning a house is now a basic requirement for Chinese couples wishing to marry, and indeed acts as social status goods for those, especially young men, who are seeking a spouse (Zhang et al. 2012). Wang (2014) argues that strengthened property rights for individuals also affects their bargaining power within the household.

In line with the literature and Giddens' thesis on disclosing intimacy and democratizing of gender relations, and believing that the three structural factors of gender, cohort and location are crucial, we outline two hypotheses in our attempt to differentiate experiences of conjugal intimacy in China:

Hypothesis 1: There will be more disclosing intimacy in the younger cohorts and 
This is the accepted version of an article published by Wiley in The British Journal of Sociology. Published version available from: https://doi.org/10.1111/1468-4446.12338

Accepted version downloaded from SOAS Research Online: http://eprints.soas.ac.uk/25219/

urban population.

Hypothesis 2: When couples self-disclose more, they will have a more egalitarian relationship in terms of division of housework, decision-making and home ownership.

\section{Method}

Data are from the China General Social Survey (CGSS) 2006. The CGSS is a national representative survey conducted annually from 2003 to 2015 by China's Renmin University, the Hong Kong University of Science and Technology and other academic institutions in collaboration with General Social Surveys in Japan, South Korea and Taiwan. CGSS 2006 included a Family Module, which collected data on different aspects of value and practice in Chinese families. Although some questions relating to family have been asked in subsequent years, CGSS 2006 collected the most comprehensive data on Chinese family practices: hence, our analysis is restricted to 2006 only. The general response rate was 51.1 per cent. Adopting a multi-stage stratified sampling design, it sampled 10,000 individual respondents from 125 primary sampling units across China. Among them, 3208 respondents aged 18-69 years were further interviewed in the Family Module. There were 2049 respondents in total after cases with missing data were removed. It should be noted that our choice of variables, described below, was shaped by existing research but also constrained by the questions asked in the CGSS.

Dependent variables: For the first hypothesis, the dependent variable is respondents' self-disclosure to their partners. Two survey questions relate to self-disclosure: 'my partner will listen to my thoughts and concerns', and 'my partner will tell me his/her thoughts and concerns'. The mean value for these two questions is used to indicate 
This is the accepted version of an article published by Wiley in The British Journal of Sociology. Published version available from: https://doi.org/10.1111/1468-4446.12338

Accepted version downloaded from SOAS Research Online: http://eprints.soas.ac.uk/25219/

self-disclosure for hypotheses 1 and 2. We coded the answers from 1-7, in ascending order of frequency of self-disclosure. For the second hypothesis, there are three dependent variables which we tested separately. The first is the gap between husbands and wives in frequency of doing housework (cooking, laundry and cleaning). We coded answers from 1-7, where 1 equals 'never' and 7 equals 'almost every day'. The scores for the three types of housework were combined, and the totals for husbands subtracted from those of wives to produce a score representing the gender gap. The division of housework is equal when the value is ' 0 '. The second dependent variable includes four areas of decision-making: child-related issues, support to elderly parents, everyday family expenditure and purchase of high-value items. Respondents stated whether decisions were taken 'mainly by myself', 'jointly', 'mainly by my partner' or 'by other family members'. Very few (around twenty) chose the fourth option, so we deleted these cases. We then classified the remaining answers as 'mainly decided by husbands', 'decided jointly' or 'mainly decided by wives'. The last dependent variable for this hypothesis is home ownership. This is a four-type categorical variable: 'owned by husband alone (including bought by husband's parents)', 'owned by both husband and wife', 'owned by others' or 'owned by wife alone (including owned by wife's parents)'.

Independent Variables: In Hypothesis 1, independent variables include gender, cohort and location. The four birth cohorts are Pre-Mao (before 1949), Mao Era (19501966), Cultural Revolution (1967-1977), and Post-Mao (after 1978). We coded location according to urban-rural division, based on the respondents' household registration status, and added an extra category of migrant, which included rural migrant workers living in urban areas. These were then coded as two dummy 
This is the accepted version of an article published by Wiley in The British Journal of Sociology. Published version available from: https://doi.org/10.1111/1468-4446.12338

Accepted version downloaded from SOAS Research Online: http://eprints.soas.ac.uk/25219/

variables. 'Migrant_urban' means urban respondents are used as the reference category in comparison with migrants. 'Rural_urban' represents urban respondents as the reference category, in comparison with rural respondents.

In Hypothesis 2, the first dependent variable has cohort, location and self-disclosure level as independent variables. For self-disclosure, the original answers range from 17; we recoded these into two categories, where 1-3 represents low self-disclosure, and 4-7 represents high self-disclosure. For the second and third dependent variables, independent variables include location and work status. The coding of location is as above. Work status is coded as a dummy variable, respectively indicating 'not working' and 'now working'.

Covariates: There are no covariates for the first hypothesis. In Hypothesis 2, for the first dependent variable (gender division of housework), previous studies find some potential influence of demographic and individual factors, such as wife's employment status (Zhang et al. 2013) and education (Evertsson and Nermo 2007). Chinese husbands with higher education than their wives have been shown to spend less time on housework, and more time on paid work than their wives (Shi et al 2016). Hence, we look at education levels (categorized as 'primary school and below', 'middle school', 'high school' and 'university and above' coded from 1-4) and cohorts (coded as above). For the second and third dependent variable, educational level, selfdisclosure level and cohorts are involved as covariates.

Analysis Strategy: For Hypothesis 1, univariate analysis is adopted to test the relations between dependent variable, independent variable and covariates. In Hypothesis 2 , 
This is the accepted version of an article published by Wiley in The British Journal of Sociology. Published version available from: https://doi.org/10.1111/1468-4446.12338

Accepted version downloaded from SOAS Research Online: http://eprints.soas.ac.uk/25219/

univariate analysis is also used to explore the interaction between housework gender gap, independent variables and covariates. For the last two dependent variables in Hypothesis 2, multi-logistic regression is used since decision-making and home ownership are both categorical variables. SPSS 22.0 was used for the analysis.

\section{Summary of Results}

\section{Level of self-disclosure}

Insert Table I

Univariate analysis [Table I] confirms that compared to rural couples, urban couples self-disclose more frequently. Cohort alone is not statistically significant, but there is significant interaction between cohort and urban-rural divide, between gender and cohort, and between gender and urban-rural divide.

\section{Insert Figure 1}

Figure 1 shows that all cohorts report relatively high self-disclosure. Among all men, self-disclosure is higher in younger cohorts; urban men are more likely than rural men to self-disclose. This partly confirms Hypothesis 1 . However, the picture for women is more complex. While younger urban women tend to self-disclose more, the pattern among rural women and migrant women is more diverse between cohorts. Older rural women experience higher levels of self-disclosure than younger cohorts. We speculate that older spouses have more time at home together in which to converse, compared with couples of working age. CGSS measured frequency of self-disclosure at a single point in time for all cohorts, which represents an earlier stage in marriage for younger respondents. Previous research has shown that couples renegotiate feelings of intimacy and interdependence over the course of a long marriage (Ingersoll-Dayton et al. 1996), and thus life-cycle may be an important aspect. We 
This is the accepted version of an article published by Wiley in The British Journal of Sociology. Published version available from: https://doi.org/10.1111/1468-4446.12338

Accepted version downloaded from SOAS Research Online: http://eprints.soas.ac.uk/25219/

cannot reach firm conclusions on this point, however as no data was recorded for the length of marriage.

\section{Democratization of marital relationships}

\section{$\underline{\text { Housework }}$}

Insert Table II: ANCOVA of Educational level, Self-disclosure, Cohort and Location on Division of Housework

Table II presents the influence of two main independent variables plus two covariates on housework sharing. This model reveals that if couples self-disclose less, there is a bigger gender gap in the allocation of housework, confirming Hypothesis 2. Urban couples share more equally than rural couples. The interaction between self-disclosure and location is significant, as illustrated in Figure 2 below, which shows that the difference in gender gap between couples with high and low levels of self-disclosure is largest for migrant couples, followed by rural couples; the smallest difference is in urban couples.

Insert Figure 2

Descriptive analysis reveals that division of housework is similar across cohorts: for all cohorts, women are responsible for most of the housework. There are no obvious regional differences. Around 70-80 per cent of wives did more housework than their partners, 1-20 per cent of couples shared equally, and 10 per cent of husbands did more than their wives. Our analysis confirms previous findings (Zhang et al. 2013) that Chinese wives do far more housework than their husbands in all locations but, 
This is the accepted version of an article published by Wiley in The British Journal of Sociology. Published version available from: https://doi.org/10.1111/1468-4446.12338

Accepted version downloaded from SOAS Research Online: http://eprints.soas.ac.uk/25219/

surprisingly, urban wives from the younger cohort take on a larger share than the older cohort. This may reflect a limitation of the survey, which took no account of the growing popularity among urban families of employing maids (baomu). The CGSS survey questions do not allow us to measure the availability of paid domestic help, but existing research suggests middle-class wives may remain nominally responsible for housework, while employing other people to do the work on their behalf (Sun 2009).

\section{Decision-making}

\section{Insert Table III}

Table III illustrates the logistic regression on four types of decision-making with two independent variables plus three covariates. Analysis of results on household decision-making shows different, gendered patterns in relation to each type of decision, not all pointing to the democratization of gender relationships.

Child-related issues and support to elderly parents: women in younger cohorts are more likely than men to make decisions on their own or jointly. The relationship between these two types of decision-making and self-disclosure is not statistically significant, so Hypothesis 2 is not supported. The dominant trend in all cohorts and locations is for joint decision-making concerning children and elderly parents. For migrant and rural couples, the percentage taking joint decisions declined slightly in the post-Mao cohort, but remained above fifty per cent. In urban and rural families, women's decision-making power is greater among younger cohorts, but in migrant families, men's decision power is larger in younger cohorts, contradicting previous findings (Connelly et al 2010). We question whether the greater power of urban and rural women over decisions concerning children and care of the elderly is a strong 
This is the accepted version of an article published by Wiley in The British Journal of Sociology. Published version available from: https://doi.org/10.1111/1468-4446.12338

Accepted version downloaded from SOAS Research Online: http://eprints.soas.ac.uk/25219/

indicator of modernity and growing equality: rather, it seems that, as Shu et al. (2013) have suggested, traditional gender roles are being reinscribed.

Everyday household expenditure: self-disclosure levels are significant as couples who self-disclose are more likely to have women decide alone or jointly than men deciding alone. Location is also significant, as urban families are more likely than rural families to have decisions taken by women alone than by men alone. This largely confirms Hypothesis 2. Around half the couples across all cohorts decide jointly on everyday family expenditure, making this the most dominant pattern. Urban women (about 25 per cent) are consistently more likely than urban men to decide on everyday expenditure. Rural husbands and wives are equally likely to take these decisions alone, but rural men are more likely than urban men to decide alone. Migrant men are more likely than women to decide alone in younger cohorts.

High-value purchases: when couples decide on the purchase of high-value items, more than half decide jointly. Self-discourse levels have no statistical significance, disproving Hypothesis 2. If the respondents have higher education, these decisions are more likely to be taken by wives alone than by husbands alone or jointly. Compared to rural families, in migrant families decisions are more likely taken by men alone than by wives alone or jointly. If the decision is taken by only one spouse, however, rural men and migrant men are more likely than their wives to hold the power.

\section{Home ownership}

Insert Table IV 
This is the accepted version of an article published by Wiley in The British Journal of Sociology. Published version available from: https://doi.org/10.1111/1468-4446.12338

Accepted version downloaded from SOAS Research Online: http://eprints.soas.ac.uk/25219/

Multivariate analysis of the data on self-disclosure and home ownership reveals important differences by location, gender and cohort. Table IV indicates the logistic regression on home ownership with two independent variables plus three covariates. Firstly, when there is more self-disclosure, houses are more likely to be owned by husbands alone, compared to the other three kinds of ownership. This appears to disprove Hypothesis 2 with regard to disclosing intimacy and the democratization of gender relationships.

Compared to older generations, younger women are more likely to live in a house they own than one owned jointly or by their husbands alone. This does demonstrate modern norms of gender equality. The one-child policy may also be influential, as parents of only daughters may buy them houses. Compared to rural couples, urban and migrant respondents are more likely to live in a house owned by the husband alone than in a house owned by the wife or jointly. In urban areas, descriptive analysis reveals that joint ownership is 37.6 per cent in the older generation compared to 22.7 per cent in the younger generation and is replaced by ownership by men (42.4 per cent) as the dominant form in the younger generation. This may be explained by increasing gender inequalities in the labour market, soaring housing prices and the social norm that a husband should provide the marital home; although newlyweds are no longer expected to reside with the husband's parents, the patrilocal pattern of residence has evolved into male ownership of the house.

Compared to migrants and urban respondents, rural women are more likely to own a house, alone or jointly, than live in houses owned by men alone. Around 20 per cent of rural women own their homes in the younger generation. We are surprised by this 
This is the accepted version of an article published by Wiley in The British Journal of Sociology. Published version available from: https://doi.org/10.1111/1468-4446.12338

Accepted version downloaded from SOAS Research Online: http://eprints.soas.ac.uk/25219/

finding, as qualitative studies suggest that inheritance of land and property is still highly gendered in rural China (Liu 2013). The registration of names on property deeds is inefficient and unreliable (Zhang 2015). We speculate that female respondents over-reported their home ownership and may not have legal possession of their homes. Our rural/urban comparison adds more nuanced analysis to the findings of a 2010 national survey which show that only 13.2 per cent of married women in China have homes in their own names, compared with 51.7 per cent of married men (Fincher 2014). The dominance of men as home-owners reflects the enduring patriarchal tradition and the contemporary cultural norm that a suitable husband should own a house.

Our findings in relation to two hypotheses are summarized in Table V. Insert Table V

\section{Discussion and conclusion}

Our analysis provides a richer empirical picture of the diversity of intimate relationships in contemporary China, adding nuance to existing theories of intimacy and modernity in a global context by demonstrating how the positioning of individuals within society - for example, by gender, location, and cohort - affects their relation with intimacy and modernity. Modernity cannot be an identical process for all. Smart and Shipman (2004), for instance, demonstrate that modern, industrialized societies are not culturally homogeneous, and being intimate in marriage entails constant and repeated renegotiation of relationships against a complex backdrop of histories, tradition, migrations and class differences. Modernity is lived from different locations (Jackson 2015). 
This is the accepted version of an article published by Wiley in The British Journal of Sociology. Published version available from: https://doi.org/10.1111/1468-4446.12338

Accepted version downloaded from SOAS Research Online: http://eprints.soas.ac.uk/25219/

We consider four factors relevant to the differentiated experiences of modernity in reform-era China. First is the persistence of cultural values, specifically those of the patrilineal family, which continue to shape intimate relationships in terms of gender roles. Second, the urban/rural divide, institutionalized through the hukou system, means unequal access to the benefits of modernity in terms of employment, education, pensions and other social welfare support. Third is the huge impact of birth-planning regulation complicated by its differentiated implementation in urban and rural China, resulting in very different patterns of family socialization for sons and daughters in urban and rural households. The contrasting expectations and behavioural norms of urban and rural women are particularly striking: in urban China where the one-child policy was strictly implemented through workplace punishment, girls enjoy unprecedented parental investment and access to better paid jobs than rural women (Liu 2017), while in rural China - where the average household has at least two children - women tend to be more obedient than urban women and are often socialized to make sacrifices for the sake of their siblings and parents (Liu 2013). Finally, rural-urban labour migration since the 1980s has created a new social group who must renegotiate their marital relationships in the context of physical separation, uneven earnings and social exclusion in the cities. This study has set out to show how many of these circumstances interact, leading to quite varied experiences of intimacy and modernity among people located differently within the social structure.

Our first major finding confirms Jamieson's (2011) observation that self-disclosure may not be a useful measure of intimacy in all cultural contexts. Self-disclosure may only be appropriate for a particular group in specific environment: for example, we 
This is the accepted version of an article published by Wiley in The British Journal of Sociology. Published version available from: https://doi.org/10.1111/1468-4446.12338

Accepted version downloaded from SOAS Research Online: http://eprints.soas.ac.uk/25219/

found that older rural couples may self-disclose more because they are at a stage in life when they spend more time together at home. Liu and Feldman (2013) use CGSS 2006 data to show that emotional support (based on the self-disclosure questions) correlates negatively with life satisfaction for husbands and wives; they speculate that people with greater psychological or other problems may self-disclose more.

Following Jamieson $(1998,2011)$ we suggest future research considers other ways in which couples express intimacy, such as through the performance of certain actions or household tasks which benefit the other.

Finally, we explored democratization in intimate relationships and showed that while higher levels of self-disclosure correlated positively with more equal sharing of housework and decisions on everyday expenditure, this was not true for home ownership or decisions concerning high-value purchases. As described in the literature on other Asian societies with a strongly patriarchal family tradition (Donner 2008; Chang and Song 2010) we find that gender norms persist despite social and economic development.

Men continue to dominate as home owners, particularly within the urban population. We understand this as a combined consequence of patrilocal and patrilineal tradition and gender inequality in the Chinese labour market: in 2010, 45.1 per cent of professionals in state-owned companies and civic institutions were women; however they constituted only 16.8 per cent of senior managers, legislators and officials (Hausmann et al. 2011). The move to more affective, communicative conjugal relationships goes hand in hand with the ideal of the bridegroom bringing significant material goods to the marriage. The traditional patrilocal family model has been 
This is the accepted version of an article published by Wiley in The British Journal of Sociology.

Published version available from: https://doi.org/10.1111/1468-4446.12338

Accepted version downloaded from SOAS Research Online: http://eprints.soas.ac.uk/25219/

reinscribed in modern times: while in the past newly-weds lived at first with the husband's parents, before the family property was divided, now they are more likely to live alone, but it remains the case that the man should provide the house. We therefore question the democratization of gender relations, following Jackson et al. (2013) in confirming that while tradition is reshaped in modern societies, it does not altogether disappear.

Our findings on migrant households are particularly interesting, as it appears that migrant men are more likely to take decisions alone than jointly. This contradicts evidence from a small study of migrants in Beijing (Zhang et al. 2013) that migrant wives had higher status but somewhat confirms the finding of Choi and Peng (2016) that changing familial practices and compromises in masculinity did not necessarily bring in gender equality within migrant households in South China. Migrant households occupy an anomalous position in relation to modernity, accessing new forms of work in the marketized economy, yet remaining excluded from urban public goods by the state programme of 'differential citizenship' (Wu 2011). Meanwhile, the experiences of migrant men and women challenge attempts to draw a clear-cut distinction between 'urban' and 'rural' models of modernity in China. Chinese rural society has not remained untouched by modernity despite its relative lack of industrialization: interactions between left-behind family members and their migrant kin bring new expectations of gender relations, at the same time as the separation caused by labour migration constrains the ability of families to maintain traditional forms of support. 
This is the accepted version of an article published by Wiley in The British Journal of Sociology. Published version available from: https://doi.org/10.1111/1468-4446.12338

Accepted version downloaded from SOAS Research Online: http://eprints.soas.ac.uk/25219/

The advantages of a large-scale quantitative study like CGSS include enabling the cross-regional, cohort and gender comparisons which we have made in this study, extending previous qualitative research on marital relations in more specific local contexts. Nevertheless, we note potential limitations deriving from the survey design. One is the range of possible answers, which are given in subjective terms rather than absolute units. Secondly, in surveys containing questions about marriage, the gender of the interviewer has been found to prompt responses conforming to socially acceptable gender norms (Liu and Stainback 2013). Furthermore, the survey might have been completed in the presence of other family members, leading respondents to answer in ways which preserve face. We hope that future quantitative research on intimate relations in China may be designed to overcome some of these methodological problems, complemented by qualitative studies adding greater depth to our understanding of what is in many ways a subjective human experience shaped by local circumstances.

\section{References}

Alwin, Duane F., and Ryan J. McCammon. 2003. 'Generations, Cohorts, and Social Change.' Handbook of the Life Course. Springer US, 23-49.

Baker, H.D.R. 1979 Chinese Family and Kinship, London: Macmillan.

Bauman, Z. 2003 Wasted Lives: Modernity and its Outcasts. Cambridge: Polity Press.

Beck, U. and Beck-Gernsheim, E. 1995 The Normal Chaos of Love, Cambridge: Polity Press. 
This is the accepted version of an article published by Wiley in The British Journal of Sociology. Published version available from: https://doi.org/10.1111/1468-4446.12338

Accepted version downloaded from SOAS Research Online: http://eprints.soas.ac.uk/25219/

Chang, K.-S. and Song, M.-Y. 2010 'The Stranded Individualizer under Compressed Modernity: South Korean Women in Individualization without Individualism', British Journal of Sociology 61(3): 539.

Chen, J.Y.-Y. and Lim, S.-L. 2012 'Factors Impacting Marital Satisfaction among Urban Mainland Chinese Women: A Qualitative Study', Asia Pacific Journal of Counselling and Psychotherapy 3: 149-60.

Chen, L.J., Yang, D.L., and Ren, Q. 2015 Report on the State of Children in China, Chicago: Chapin Hall at the University of Chicago. Available from http://www.chapinhall.org/research/report/report-state-children-china. Accessed 7 November 2017.

China News Weekly 2015 'Single people reaching two billion in China', 27 November 2015. Available from http://news.sohu.com/20151127/n428592875.shtml. Accessed 20 Mar 2016.

Choi, S. P. and Peng, Y. N. 2016 Masculine Compromise: Migration, Family and Gender in China, Oakland, CA: University of California Press.

Connelly, R., Roberts, K. and Zheng, Z. 2010 'The Impact of Circular Migration on the Position of Married Women in Rural China', Feminist Economics 16(1): 3-41.

Cook, S., and Dong, X.-Y. 2011 'Harsh Choices: Chinese Women's Paid Work and Unpaid Care Responsibilities under Economic Reform, Development \& Change 42(4): 947-965.

Croll, E. 1979 The Politics of Marriage in Contemporary China, Cambridge:

Cambridge University Press.

Croll, E. 1983 Chinese Women Since Mao, London: Zed Books.

Dirlik, A. and Zhang, H. 1997 Postmodernism and China, Durham, N.C: Duke University Press. 
This is the accepted version of an article published by Wiley in The British Journal of Sociology. Published version available from: https://doi.org/10.1111/1468-4446.12338

Accepted version downloaded from SOAS Research Online: http://eprints.soas.ac.uk/25219/

Donner, H. 2008 Domestic Goddesses: Maternity, Globalization and Middle-Class

Identity in Contemporary India, Aldershot: Ashgate.

Duncan, S. and Irwin, S. 2004 'The Social Patterning of Values and Rationalities:

Mothers' Choices in Combining Caring and Employment', Social Policy and Society, 3(4): 391-99.

Evertsson, M. and Nermo, M. 2007 'Changing Resources and the Division of Housework: A Longitudinal Study of Swedish Couples', European Sociological Review 23: 455.

Farrer, J. 2002 Opening up: Youth Sex Culture and Market Reform in Shanghai, Chicago: University of Chicago Press.

Fincher, L. 2014 Leftover Women: The Resurgence of Gender Inequality in China, London: Zed Books.

Giddens, A. 1991 Modernity and Self-Identity: Self and Society in the Late Modern Age, John Wiley and Sons.

Giddens, A. 1992 The Transformation of Intimacy: Sexuality, Love, and Eroticism in Modern Societies, Stanford: Stanford University Press.

Guo, Wei (2013) 'The Reason for the Expanding Parity between Urban and Rural China', 13 January, Institute of Rural China Studies. [In Chinese].

Hannum, E., Wang, M. and Adams, J. 2010 'Urban-Rural Disparities in Access to Primary and Secondary Education under Market Reforms' in M.K. Whyte (ed.) One Country, Two Societies: Rural-Urban Inequality in Contemporary China, Boston: Harvard University Press.

Hashimoto, A. and Traphagan, J.W. (eds) 2008 Imagined Families, Lived Families: Culture and Kinship in Contemporary Japan, Albany, NY: SUNY Press. 
This is the accepted version of an article published by Wiley in The British Journal of Sociology. Published version available from: https://doi.org/10.1111/1468-4446.12338

Accepted version downloaded from SOAS Research Online: http://eprints.soas.ac.uk/25219/

Hausmann, R., Tyson, L.D. and Zahidi, S. 2011 Global gender gap report, Geneva: World Economic Forum.

Hershatter, G. 2000 Women in China's Long Twentieth Century, Berkeley, CA:

University of California Press.

Hochschild, A.R. and Machung, A. 1989 The Second Shift: Working Parents and the Revolution at Home, London: Penguin.

Illouz, E. 1997 Consuming the Romantic Utopia: Love and the Cultural Contradictions of Capitalism, Berkeley, CA: University of California Press.

Ingersoll-Dayton, B., Campbell, R., Kurokawa, Y., and Saito, M. 1996

'Separateness and Togetherness: Interdependence over the Life Course in Japanese and American Marriages', Journal of Social and Personal Relationships 13(3): 385. Jackson, S., Ho, P., and Na, J. 2013 'Reshaping tradition? Women negotiating the boundaries of tradition and modernity in Hong Kong and British families', Sociological Review 61(4): 667-87.

Jackson, S. 2015 'Modernity/Modernities and Personal Life: Reflections on Some Theoretical Lacunae', Korean Journal of Sociology, 49(3): 1-20.

Jamieson, L. 1998 Intimacy: Personal Relationships in Modern Societies, Cambridge: Polity Press.

Jamieson, L. 1999 'Intimacy Transformed? A Critical Look at the `Pure Relationship', Sociology, 33(3):477-494.

Jamieson, L. 2011 'Intimacy as a concept', Sociological Research Online, 16(4).

Jankowiak, W. and Li, X. 2017 'Emergent Conjugal Love, Mutual Affection, and Female Marital Power', in G. Santos and S. Harrell (eds) Transforming Patriarchy: Chinese Families in the $21^{\text {st }}$ Century, Seattle: University of Washington Press. Judd, E. 1994 Gender and Power in Rural North China. Stanford University Press. 
This is the accepted version of an article published by Wiley in The British Journal of Sociology. Published version available from: https://doi.org/10.1111/1468-4446.12338

Accepted version downloaded from SOAS Research Online: http://eprints.soas.ac.uk/25219/

Knight, J, and L. Song. 1999 The Rural-Urban Divide: Economic Disparities and Interactions in China, Oxford: Oxford University Press.

Kulik, L. 2011 'Developments in Spousal Power Relations: Are We Moving Toward Equality?' Marriage and Family Review 47: 419.

Kuo, M. 2012 Intolerable Cruelty: Marriage, Law and Society in Early TwentiethCentury China, Lanham, MD: Rowman and Littlefield.

Liao, F.H.F. and Wei, Y.D. 2012 'Dynamics, Space, and Regional Inequality in Provincial China: a Case Study of Guangdong Province', Applied Geography 35: 7183.

Lišková, K. 2016. 'Sex under Socialism: From Emancipation of Women to Normalized Families in Czechoslovakia', Sexualities 191-2): 211-235.

Liu, H., Li, S., and Feldman, M. 2013 'Gender in Marriage and Life Satisfaction Under Gender Imbalance in China: The Role of Intergenerational Support and SES', Social Indicators Research 114(3): 915-33.

Liu, J. 2004 'Holding Up the Sky? Reflections on Marriage in Contemporary China'. Feminism and Psychology, 14(1): 195-202.

Liu, J. 2007 Gender and Work in Urban China: Women Workers of the Unlucky Generation. London: Routledge.

Liu, J. 2014 'Ageing, Migration and Familial Support in Rural China'. Geoforum, 51: 305-312.

Liu, J. 2017 Gender, Sexuality and Power in Chinese Companies: Beauties at Work. Basingstoke: Palgrave MacMillan.

Liu, M. and Stainback, K. 2013 'Interviewer Gender Effects on Survey Responses to Marriage-Related Questions', Public Opinion Quarterly 77(3): 606-18. 
This is the accepted version of an article published by Wiley in The British Journal of Sociology. Published version available from: https://doi.org/10.1111/1468-4446.12338

Accepted version downloaded from SOAS Research Online: http://eprints.soas.ac.uk/25219/

Mann S and Zhang Y.Y. (eds) 2001 Under Confucian Eyes. Berkeley: University of California Press.

Pan, L. 2015 When True Love Came to China, Hong Kong: Hong Kong University Press.

Parsons, Talcott, Robert F. Bales, and James Olds. 1956. Family: Socialization and Interaction Process. London: Routledge \& Kegan Paul.

Pimentel, E.E. 2000 'Just How Do I Love Thee? Marital Relations in Urban China', Journal of Marriage and Family 62(1): 32-47.

Pimentel, E.E. 2006 'Gender Ideology, Household Behavior, and Backlash in Urban China', Journal of Family Issues 27(3): 341-65.

Shi, F. et al. 2016 'Bargaining Power and the Household Division of Labour:

Evidence from 2008 China Time-Use Survey', Asia-Pacific Population Journal 31.1.

Shu, X., Zhu, Y. and Zhang, Z. 2013 'Patriarchy, Resources, and Specialization:

Marital Decision-Making Power in Urban China', Journal of Family Issues 34(7): $885-917$.

Smart, C. and Shipman, B. 2004 'Visions in Monochrome: Families, Marriage and the Individualization Thesis', British Journal of Sociology 55(4): 491-509.

Stacey, J. 1996 In the Name of the Family: Rethinking Family Values in the Postmodern Age, Boston: Beacon Press.

Sun, W. 2009 Maid in China: Media, Morality and the Cultural Politics of Boundaries, London: Routledge.

Twamley, K. 2014 Love, Marriage and Intimacy among Gujarati Indians: A Suitable Match, Basingstoke: Palgrave Macmillan.

Wang, Q. 2001 'China's Divorce Trends in the Transition toward a Market Economy', Journal of Divorce and Remarriage 35(1-2): 173-89. 
This is the accepted version of an article published by Wiley in The British Journal of Sociology. Published version available from: https://doi.org/10.1111/1468-4446.12338

Accepted version downloaded from SOAS Research Online: http://eprints.soas.ac.uk/25219/

Wang, S. 2014 'Property Rights and Intra-household Bargaining', Journal of Development Economics 192-201.

Wolf, M. 1972 Women and the Family in Rural Taiwan, Stanford, CA: Stanford University Press.

Wu, J. 2011 'Strangers Forever? Differential Citizenship and China's Rural Migrant Workers', Taiwanese Sociology 21: 51.

Xu, X.H. 1999 'Convergence or Divergence: The Transformation of Marriage Relationships in Urban America and Urban China', Journal of Asian and African Studies 33:181-204.

Yan, Y. 2003 Private Life under Socialism: Love, Intimacy, and Family Change in a Chinese Village, 1949-1999, Stanford, CA: Stanford University Press.

Zhang, C.H., Gao, Q.J. and Li, X.Y. 2013 'The Impact of Rural-Urban Migration on Gender Relations in Chinese Households', Asian Journal of Women's Studies 19: $41-66$.

Zhang, H., Xu, X. and Tsang, S. 2012 'Conceptualizing and Validating Marital Quality in Beijing: A Pilot Study', Social Indicators Research 113:197-212.

Zhang, L. 2015 'A Study of the Rural Home Ownership Registration System', Academic Theory 325. [In Chinese]

Zhang, W. 2000 'Dynamics of Marriage Change in Chinese Rural Society in Transition: A Study of a Northern Chinese Village', Population Studies 54: 57-69.

Zuo, J. and Bian, Y. 2005 'Beyond Resources and Patriarchy: Marital Construction of Family Decision-Making Power in Post-Mao Urban China', Journal of Comparative Family Studies 36(4): 600--622. 